Jurnal Abdidas Volume 1Nomor 1 Tahun 2020 Halaman 7-11

JURNAL ABDIDAS

Community Development Service on Educational and Health Sciences https://journal.universitaspahlawan.ac.id/index.php/abdidas/index

\title{
Pelatihan Media Berbasis IT Pembelajaran HOTS MGMP Guru MA
}

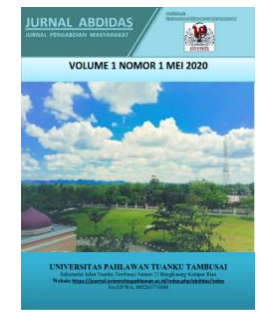

\section{Vitri Angraini Hardi ${ }^{1}$}

Universitas Pahlawan Tuanku Tambusai, Riau, Indonesia ${ }^{1}$ e-mail : vitrihardi@gmail.com ${ }^{1}$

\begin{abstract}
Abstrak
Pelatihan dan pendampingan pembuatan media pembelajaran berbasis multimedia dengan menggunakan Kahoot pada forum MGMP Sang Surya Guru MAS Kecamatan Kampar dengan peserta pelatihan adalah guru MA Swasta yang berda di Kecamatan Kampar. Untuk tahap awal, dilakukan persiapan pelatihan mulai dari pemahaman para tim pendamping peserta terhadap aplikasi Kahoot, penyusunan bahan ajar pelatihan, pembuatan kesepakatan jadwal pelatihan, sarana dan prasarana, hingga pelaksanaan pelatihan yang dilaksanakan pada mitra pengabdian yaitu MGMP Sang Surya. Pelaksanaan pelatihan menghasilkan media pembelajaran yang dibuat oleh peserta, hal ini menunjukkan pelatihan dilaksanakan sampai pada tahap peserta memiliki skill membuat media pembelajaran berbasis multimedia dengan menggunakan Kahoot. Oleh karena itu, pelatihan yang telah dilaksanakan pada mitra pertama sudah terlaksana dengan baik walaupun terdapat hambatan yang tidak signifikan.
\end{abstract}

Kata Kunci: Media, IT, Pembelajaran HOTS

\begin{abstract}
Training and assistance in making multimedia-based learning media by using Kahoot in the Sang Surya MGMP Teacher Teachers in Kampar District with the training participants being private MA teachers who are working in Kampar District. To begin, training preparations, participant companions, and training, preparation, training and preparation, preparation and training, and training are carried out for the devoted partner, MGMP Sang Surya. The training makes learning media created by participants, this shows the training is carried out until the training participants create multimedia-based learning skills using Kahoot. Therefore, the training that was carried out at the first partner had been carried out well because there was something meaningless.
\end{abstract}

Keywords: media, IT ,HOTS Learning

Copyright (c) 2020 Vitri Angraini Hardi

$\square$ Corresponding author:

Address : Alamat penulis

Email : Email Penulis

ISSN 2721-9224 (Media Cetak)

Phone : Nomor HP: 


\section{PENDAHULUAN}

Pendidikan nasional yang berdasarkan Pancasila dan Undang-undang Dasar Negara Republik Indonesia Tahun 1945 haruslah sesuai dengan tujuan pendidikan nasional. Dalam Undang-undang Dasar 1945 Pasal 31, ayat 5 menyebutkan bahwa, "Pemerintah memajukan ilmu pengetahuan dan teknologi dengan menjunjung tinggi nilai-nilai agama dan persatuan bangsa untuk kemajuan peradaban serta kesejahteraan umat manusia." Hal yang perlu digaris bawahi adalah memajukan ilmu pengetahuan dan teknologi yang bearti keduanya saling melengkapi dalam mencapai kemajuan itu sendiri. Terlebih lagi, kondisi saat ini yang sudah memasuki era globalisasi dituntut untuk melakukan percepatan dalam pemahaman pengetahuan dan teknologi.

Kemajuan ilmu pengetahuan dan teknologi secara global digambarkan dengan kemajuan teknologi informasi dan komunikasi (TIK). Hal itu bisa terlihat pada penyebaran informasi dan proses komunikasi saat ini yang tidak lagi dalam hitungan menit akan tetapi sudah bisa dikatakan per sekian detik. Selain itu, tampilan dan wujud informasi dan komunikasi itu sendiri sudah tidak lagi analog dan pasif akan tetapi sudah digital dan bersifat aktif dan interaktif. Menurut Darmawan (2011: 4) kemajuan teknologi informasi dan komunikasi dapat dilakukan pada bidang pendidikan. Lebih lanjut dikatakan ide-ide pembelajaran yang sulit dideskripsikan menjadi mudah melalui animasi-animasi yang menarik, kemudian dapat mempermudah simulasi proses-proses yang rumit.

Pendidikan yang merupakan bentuk usaha untuk menyiapkan peserta didik melalui kegiatan bimbingan, pengajaran, dan atau latihan bagi peranannya di masa yang akan datang haruslah menjadi pusat lahirnya kemajuan teknologi. Untuk mewujudkan hal tersebut, tentulah peserta didik harus dibiasakan dengan penggunaan teknologi, akan tetapi yang menjadi hambatan adalah pengetahuan guru akan teknologi. Padahal Wena (2016: 2) mengatakan guru adalah komponen penting dari tenaga kependidikan yang memiliki tugas untuk melaksanakan proses pembelajaran. Dengan demikian, guru haruslah terlebih dahulu memahami teknologi terutama teknologi dalam pembelajaran. Untuk yang lebih sederhana Wena (2016: 2) menambahkan guru harus mampu mengelola berbagai sumber daya yaitu dirinya sendiri dan media pembelajaran.

Hal ini sejalan dengan munculnya kebijakan literasi yang dicanangkan pemerintah di lingkungan sekolah. Literasi tidak terbatas pada kegiatan membaca dan menulis saja. Guru dituntut untuk mampu literasi dalam digital. Hal inilah yang kemudian memaksa guru secara berangsur angsur untuk mempelajari dan mengintegrasikan ICT ke dalam proses pembelajaran.

Minimnya penggunaan media pembelajaran yang bebasis IT di sekolah oleh guru mengakibatkan model pembelajaran yang diterapkan juga bersifat terbatas pada aktifitas fisik saja. Menurut Joice dkk (Trianto, 2017: 52) model pembelajaran adalah suatu perencanaan atau pola pembelajaran yang bertujuan menentukan materi pembelajaran salah satunya termuat dalam program- program media komputer, mengingat suatu model berfungsi mengarahkan perencanaan pembelajaran yang membantu peserta didik mencapai berbagai tujuan. Menurut Sani (2017: 9) tantangan di masa yang akan datang, salah satunya adalah kecenderungan penggunaan IT di kehidupan era globalisasi, sehingga masalah tersebut 
harus secara kontinyu diupayakan untuk diselesaikan.

Multimedia merupakan salah satu bentuk teknologi komputer yang saat ini banyak digunakan dalam bidang pendidikan. Multimedia mencakup bebagai media dalam satu perangkat lunak (software). Menurut beberapa pakar, diantaranya Furt, Haffors, Thomson dan Jayant (Munir, 2001: 13) mendefinisikan multimedia sebagai gangunagn antara berbagai media seperti teks, numerk, frafik, gambar, animasi, video, fotografi, suat dan data yang dikendalikan dengan program komputer (dalam satu software digital) serta mempunyai kemampuan interaktif, menjadi salah satu alternatif yang baik sebagai alat bantu dalam pembelajaran.

Elemen-elemen multimedia yang menggabungkan beberapa komponen seperti warna, teks, animasi, gambar/grafik, suara dan video sangat menunjang dalam memenuhi kebutuhan belajar siswa yang memiliki kemampuan kognitif yang berbeda. Konsep multimedia menurut Mayer (2001) meliputi tiga level, yaitu, pertama level teknis yang berkaitan dengan alat-alat teknik: alat-alat ini dapat dianggap sebagai kendaraan pengangkut tanda-tanda (signs); kedua, level semiotik yang berkaitan dengan bentuk representasi (yaitu teks, gambar atau grafik); bentuk representasi ini dapat dianggap sebagai jenis tanda (type of signs); ketiga, level sensorik.

Secara umum, ada 2 permasalahan dasar yang dihadapi oleh guru MA Swasta di Kabupaten Kampar, yaitu:

1. Belum adanya kegiatan pengenalan tentang literasi digital dalam pembelajaran.

2. Minimnya informasi terkait bentuk integrasi ICT dalam pembelajaran

\section{METODE}

Terkait permasalahan yang dihadapi mitra, dosen sebagai pelaksana pengabdian masyarakat $(\mathrm{PkM})$ bersama 2 orang mahasiswa akan memberikan suatu solusi untuk mengatasi kesulitan yang dialami guru dalam menemukan solusi dari permasalahan yang ada di kelas. Solusi tersebut berupa pelayanan jasa dalam bentuk pendampingan dan pelatihan media pembelajran dengan menggunakan Teknologi Informasi bagi Guru MA Swasta di Kabupaten Kampar. Dosen bertindak sebagai fasilitator terhadap penyediaan Materi Pembelajaran, sedangkan mahasiswa diperbantukan dalam proses pengontrolan dan partisipasi dalam proses kegiatan pembelajaran. Adapun solusi yang ditawarkan yaitu berupa:

1. Pemberian pendampingan berupa workshop media pembelajaran berbasis IT.

2. Pembuatan media pembelajaran berbasis IT bagi Guru MA Swasta di Kabupaten Kampar yang tergabung dalam MGMP Sang Surya.

Secara umum pelaksanaan kegiatan PkM berupa perencanaan/persiapan, pelaksanaan, observasi dan evaluasi serta refleksi.

a. Perencanaan. Kegiatan perencanaan yaitu sebagai berikut

1. Melakukan koordinasi dengan pihak pelaksana acara.

2. Melakukan pkoordinasi jadwal pelaksanaan kegiatan.

3. Menjelaskan mengenai pentingnya ketersiapan guru dalam kegiatan

b. Pelaksanaan

1. Penyajian materi tentang ICT dalam pembelajaran

2. Penyajian materi tentang keberadaan Gerakan Literasi.

3. Pengenalan jenis media berbasis IT 
4. Memberikan pelatihan berupa penggunaan Media Kahoot \& Edmodo pada pembelajaran.

c. Observasi dan Evaluasi. Kegiatan observasi dilakukan secara langsung oleh Tim Pelaksana. Observasi berupa pemberian tes melalui aplikasi kahoot dan penggunaan aplikasi melalui domenstrasi kegiatan oleh guru. Proses evaluasi dilaksanakan untuk mengatahui peruabahan pemahaman guru dalam pembuatan dan penggunaan media berbasis IT pada pembelajaran.

d. Refleksi. Refleksi dilakukan bersama antara tim pelaksana, siswa dan ketua pelaksana MGMP. Hal dilakukan untuk mengetahui keefektifan pelatihan berupa workshop yang diberikan.

\section{HASIL DAN PEMBAHASAN}

Kegiatan dilaksanakanLabor Komputer MAS Muhammadiyah Penyesawan Kecamatan Kampar Kabupaten Kampar. dalam program PKM ini meliputi pemberian workshop/ pelatihan kepada guru melalui forum MGMP Sang Surya dengan jumlah peserta workshop sebanyak 20 orang. Adapun kegiatan meliputi:

1. Diskusi terkait kesulitan guru dalam penggunaan media pembelajaran berbasis IT. Kegiatan ini dilaksanakan pada bulan Desember 2019. Dosen bersama ketua pelaksana MGMP melakukan diskusi terkait kebutuhan guru MAS Kecamatan Kampar tentang penggunaan media pembelajaran berbasis IT bagi peserta didik.

2. Analisis kebutuhan lain untuk pelatihan dan memperoleh solusinya meliputi jadwal pelaksanaan kegiatan sebanyak 5 kali pertemuan, konsumsi kegiatan selama pelatihan berlangsung, dan peserta pelatihan yang memiliki komitmen untuk kontinyu menjadi peserta pelatihan. Peserta dipilih berdasarkan semangat guru untuk mempelajari pembuatan media pembelajaran berbasis multimedia interaktif dan persepsi guru mengenai media pembelajaran berbasis multimedia interaktif. Sembilan orang peserta menyatakan selalu menggunakan media dalam melaksanakan pembelajaran, akan tetapi delapan dari sembilan orang tersebut tidak pernah menggunakan media pembelajaran berbasis multimedia selain $M s$. Power Point. Hal ini menunjukkan media sering digunakan dalam pembelajaran, hanya saja belumlah interaktif.

3. Membuat perancangan sistem dilakukan dengan koordinasi antar anggota tim pelaksana berdasarkan hasil diskusi dan analisis kebutuhan lain. Perancangan sistem meliputi susunan acara, pengisi acara, hingga tugas-tugas anggota tim. Susunan pelaksanaan kegiatan terdiri dari pembukaan, pelatihan, pendampingan, presentasi dan penutup.

a. Pembukaan, dipandu oleh pembawa acara yaitu mahyuddin,S.Pd I selaku ketua MGMP Sang Surya. Kegiatan dimulai dengan membuka acara pembukaan yaitu dengan mengucapkan Basmalah. Kemudian, kata sambutan dari ketua pelaksana yaitu Khairul Mizan dan dilanjutkan dengan sambutan dan membuka kegiatan pelatihan oleh Narasumber (dosen).

b. Pelatihan dilakukan oleh ketua pelaksana bersama anggota tim dan dibantu oleh mahasiswa. Pelatihan dimulai dengan penyampaian materi yaitu pentingnya literasi digital dan jenis media pembelajaran berbasis IT.

c. Pendampingan berupa kegiatan mendampingi peserta pelatihan dalam membuat media pembelajaran 
berbasis multimedia interaktif menggunakan aplikasi Kahoot dan Edmodo. Kegiatan ini juga dilakukan oleh semua anggota tim pelaksana kegiatan pelatihan. Pendampingan dilakukan hingga peserta menghasilkan suatu media pembelajaran berbasis multimedia interaktif menggunakan aplikasi Kahoot dan Edomodo secara utuh.

d. Presentasi direncanakan akan dilakukan oleh peserta, yaitu mempresentasikan media pembelajaran berbasis multimedia interaktif menggunakan aplikasi Kahhot yang telah dibuat selama pendampingan. Presentasi dilakukan dihadapan para peserta yang lain dan tim pelaksana.

e. Penutup sebagai akhir dari kegiatan pelatihan yaitu dipandu oleh pembawa acara dengan susunan acara ucapan terima kasih kepada mitra oleh ketua pelaksana, kemudian kesan dan pesan sekaligus menutup kegiatan pelatihan oleh ketua mitra.

4. Membuat materi yang berkenaan dengan pengembangan media pembelajaran berbasis multimedia interaktif menggunakan aplikasi Kahoot Materi disusun dalam bentuk buku panduan pembuatan media pembelajaran berbasis multimedia interaktif menggunakan aplikasi Kahoot

\section{SIMPULAN}

Pelatihan dan pendampingan pembuatan media pembelajaran berbasis multimedia dengan menggunakan Kahoot pada forum MGMP Sang Surya Guru MAS Kecamatan Kampar dengan peserta pelatihan adalah guru MA Swasta yang berda di Kecamatan Kampar. Untuk tahap awal, dilakukan persiapan pelatihan mulai dari pemahaman para tim pendamping peserta terhadap aplikasi Kahoot, penyusunan bahan ajar pelatihan, pembuatan kesepakatan jadwal pelatihan, sarana dan prasarana, hingga pelaksanaan pelatihan yang dilaksanakan pada mitra pengabdian yaitu MGMP Sang Surya. Pelaksanaan pelatihan menghasilkan media pembelajaran yang dibuat oleh peserta, hal ini menunjukkan pelatihan dilaksanakan sampai pada tahap peserta memiliki skill membuat media pembelajaran berbasis multimedia dengan menggunakan Kahoot. Oleh karena itu, pelatihan yang telah dilaksanakan pada mitra pertama sudah terlaksana dengan baik walaupun terdapat hambatan yang tidak signifikan.

\section{DAFTAR PUSTAKA}

Darmawan, Deni. 2011. Teknologi Pembelajaran. Bandung: Remaja Rosdakarya.

Sani, Abdullah Ridwan. 2017. Pembelajaran Saintifik unruk Implementasi Kurikulum 2013. Jakarta: Bumi Aksara.

Trianto. 2017. Model Pembelajaran Terpadu: konsep, strategi, dan implementasinya dalam kurikulum tingkat satuan pendidikan (KTSP). Jakarta: Bumi Aksara.

Wena, Made. 2016. Strategi Pembelajaran Inovatif Kontemporer Suatu Tinjauan Konseptual Operasional. Jakarta: Bumi Aksara.. 